Provided for non-commercial research and education use. Not for reproduction, distribution or commercial use.

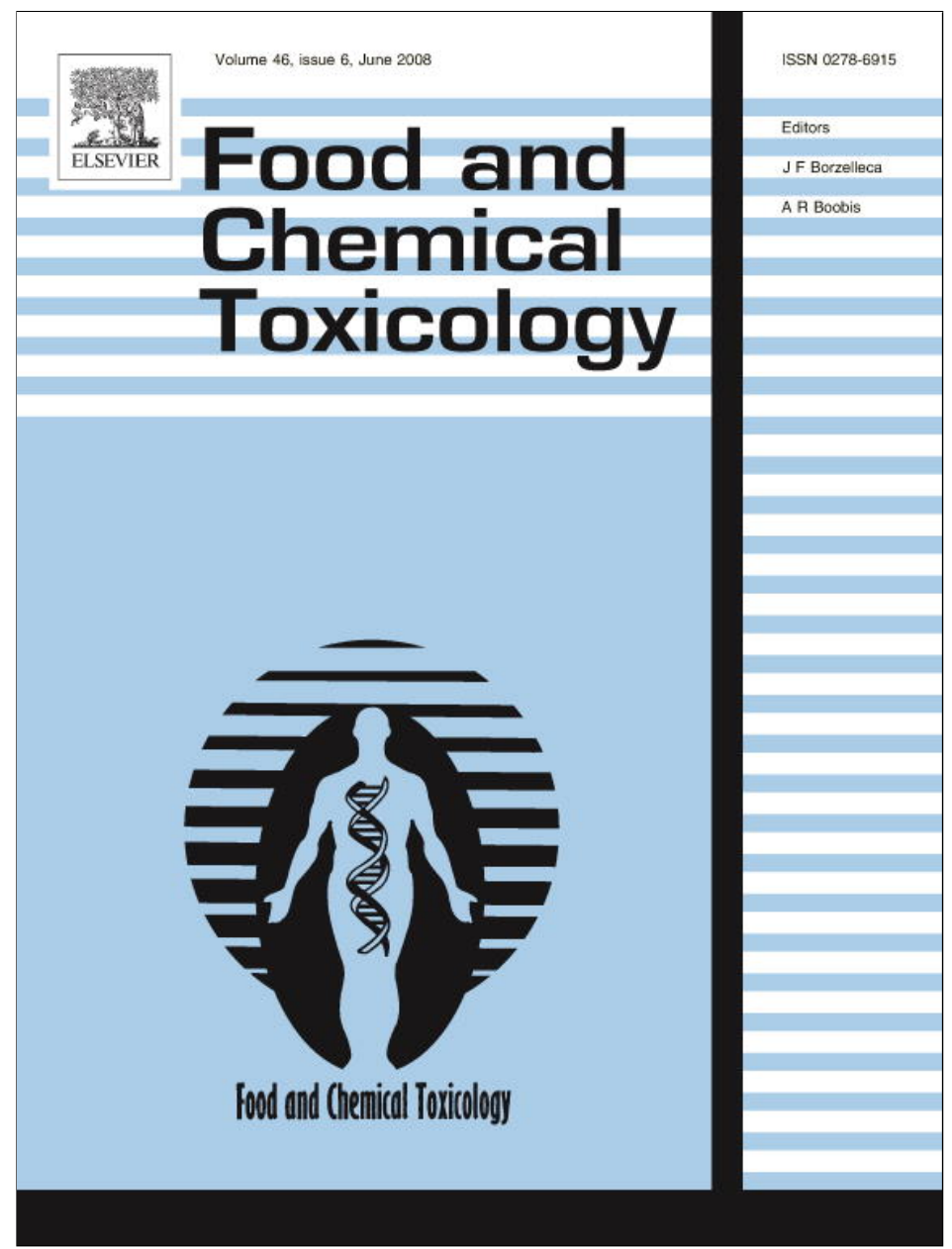

This article appeared in a journal published by Elsevier. The attached copy is furnished to the author for internal non-commercial research and education use, including for instruction at the authors institution and sharing with colleagues.

Other uses, including reproduction and distribution, or selling or licensing copies, or posting to personal, institutional or third party websites are prohibited.

In most cases authors are permitted to post their version of the article (e.g. in Word or Tex form) to their personal website or institutional repository. Authors requiring further information regarding Elsevier's archiving and manuscript policies are encouraged to visit:

http://www.elsevier.com/copyright 


\title{
Antioxidant activity and bioactive compounds of ten Portuguese regional and commercial almond cultivars
}

\author{
João C.M. Barreira ${ }^{\mathrm{a}, \mathrm{b}}$, Isabel C.F.R. Ferreira ${ }^{\mathrm{a}, *}$, M. Beatriz P.P. Oliveira ${ }^{\mathrm{b}}$, José Alberto Pereira ${ }^{\mathrm{a}}$ \\ ${ }^{a}$ CIMO/Escola Superior Agrária, Instituto Politécnico de Bragança, Campus de Santa Apolónia, Apartado 1172, 5301-855 Bragança, Portugal \\ ${ }^{\mathrm{b}}$ REQUIMTE/Serviço de Bromatologia, Faculdade de Farmácia da Universidade do Porto, Rua Aníbal Cunha, 164, 4099-030 Porto, Portugal
}

\section{A R T I C L E I N F O}

\section{Article history:}

Received 5 September 2007

Accepted 27 February 2008

\section{Keywords:}

Almond

Antioxidants

Scavenging effects

Peroxidation

Hemolysis inhibition

\begin{abstract}
A B S T R A C T
The antioxidant properties of different almond cultivars (cv.), either regional (Casanova, Duro Italiano, Molar, Orelha de Mula and Pegarinhos cv.) or commercial (Ferraduel, Ferranhês, Ferrastar and Guara cv.) were evaluated through several chemical and biochemical assays: DPPH (2,2-diphenyl-1-picrylhydrazyl) radical scavenging activity, reducing power, inhibition of $\beta$-carotene bleaching, inhibition of oxidative hemolysis in erythrocytes, induced by 2,2'-azobis(2-amidinopropane)dihydrochloride (AAPH), and inhibition of thiobarbituric acid reactive substances (TBARS) formation in brain cells, all used as models for the lipid peroxidation damage in biomembranes. The $\mathrm{EC}_{50}$ values were calculated for all the methods in order to evaluate the antioxidant efficiency of each almond cultivar. Bioactive compounds such as phenols and flavonoids were also obtained and correlated to antioxidant activity. The results obtained were quite heterogeneous, revealing significant differences among the cultivars assayed. Duro Italiano $\mathrm{cv}$. revealed better antioxidant properties, presenting lower $\mathrm{EC}_{50}$ values in all assays, and the highest antioxidants contents. The protective effect of this cultivar on erythrocyte biomembrane hemolysis was maintained during $4 \mathrm{~h}$.
\end{abstract}

(c) 2008 Elsevier Ltd. All rights reserved.

\section{Introduction}

Edible nuts are cultivated in a variety of growing conditions and climates; they are globally popular and valued for their sensory, nutritional, and health attributes (Venkatachalam and Shridhar, 2006). Almond, scientifically known as Prunus dulcis, belongs to the family Rosaceae, being almond tree the number one tree nut produced on a global basis (Chen et al., 2005; Subhashinee et al., 2006). It is especially spread through and well adapted to the whole Mediterranean region, from which about $28 \%$ of the world production is obtained. In Portugal, almond is a traditional crop, mainly spread through Algarve and Baixo Alentejo in the south, and "Terra Quente Transmontana" in the north. In fact, almond tree is an important crop, due to its fruits of high commercial value (Cordeiro and Monteiro, 2001; Martins et al., 2003; Moure et al., 2007). There is a great diversity of almonds which exhibit different productivity and yields of seed in the fruit (Martínez et al., 1995). Almond, with or without the brown skin, is consumed as the whole nut or used in various confectioneries (Subhashinee et al., 2006).

It is well-known that fruits and nuts contain a wide variety of phenolic acids and flavonoids that are predominantly conjugated

\footnotetext{
* Corresponding author. Tel.: +351 273 303219; fax: +351 273325405

E-mail address: iferreira@ipb.pt (I.C.F.R. Ferreira).
}

with sugars or other polyols via 0 -glycosidic bonds or ester bonds (Milbury et al., 2006) and its consumption has been associated with reduced risk of chronic diseases (Pellegrini et al., 2006). The Prunus genus is reported to have interesting biological properties such as sedative, anti-inflammatory, anti-hyperlipidemic, anti-tumoral and antioxidant activities (Donovan et al., 1998; Wang et al., 1999; Sang et al., 2002). Reactive oxygenic species (ROS) in the form of superoxide anion $\left(\mathrm{O}_{2}^{-\cdot}\right)$, hydrogen peroxide $\left(\mathrm{H}_{2} \mathrm{O}_{2}\right)$ and hydroxyl radical ( $\mathrm{HO}^{*}$ ) are natural by-products of our body's metabolism. However, when present in excess, they can attack biological molecules such as lipids, proteins, enzymes, DNA and RNA, leading to cell or tissue injury associated with degenerative diseases (Amarowicz et al., 2004). Although the mammalian body has certain defense mechanisms to combat and reduce oxidative damage, epidemiological evidence indicates that the consumption of foodstuffs containing antioxidant phytonutrients - notably the above mentioned flavonoids and other polyphenolics - is advantageous for our health (Amarowicz et al., 2004). The additive and synergistic effects of such bioactive molecules present in plant food are responsible for their potent antioxidant properties (Pellegrini et al., 2006; Pereira et al., 2006). Dietary antioxidants provide protection against oxidative attack by decreasing oxygen concentration, intercepting singlet oxygen, preventing first-chain initiation by scavenging initial radicals, binding of metal ion catalysts, decomposing primary products of oxidation to nonradical 
compounds, and chain breaking to prevent continuous hydrogen removal from substrates (Subhashinee et al., 2006).

Extracts of whole almond seed, brown skin, and green shell cover possess potent free radical scavenging capacities. These activities may be related to the presence of flavonoids and other phenolic compounds in nuts (Subhashinee et al., 2006). Nevertheless, few studies reporting almond antioxidant potential are available. Research has only been made on bioactive compound in almond hulls (Takeoka et al., 2000; Sang et al., 2002a, 2002b; Takeoka and Dao, 2003; Rabinowitz, 2004), almond skins (Sang et al., 2002a) and almond shells (Pinelo et al., 2004). Even though it has already been demonstrated that individual almond components (Takeoka et al., 2000; Sang et al., 2002a, 2002b; Takeoka and Dao, 2003; Pinelo et al., 2004; Rabinowitz, 2004) have antioxidant potential, no scientific information is available regarding almond as an whole fruit. In fact, scientific information on antioxidant properties of whole almond is still rather scarce. Hence, the evaluation of such properties remains an interesting and valuable task, particularly for finding new sources for natural antioxidants, functional foods and nutraceuticals.

Accordingly, in this work, the antioxidant properties of kernels (maintaining the brown skin) were evaluated through several chemical and biochemical assays: DPPH radical scavenging activity, reducing power, inhibition of $\beta$-carotene bleaching, inhibition of oxidative hemolysis in erythrocytes, induced by AAPH, and inhibition of thiobarbituric acid reactive substances (TBARS) formation in brain cells. Additionally, we verified if different almond cultivars revealed significant variation for its antioxidant activity, correlating it with the amounts of bioactive compounds quantified.

\section{Materials and methods}

\subsection{Standards and reagents}

Standards BHA (2-tert-butyl-4-methoxyphenol), TBHQ (tert-butylhydroquinone), L-ascorbic acid, $\alpha$-tocopherol, gallic acid and $(+)$-catechin were purchase from Sigma (St. Louis, MO, USA). 2,2-diphenyl-1-picrylhydrazyl (DPPH) was obtained from Alfa Aesar (Ward Hill, MA, USA). All other chemicals were obtained from Sigma Chemical Co. (St. Louis, MO, USA). Methanol was obtained from Pronalab (Lisbon, Portugal). Water was treated in a Mili-Q water purification system (TGI Pure Water Systems, USA).

\subsection{Samples and sample preparation}

Almond fruits, regional and commercial, were collected in August-September 2006 in orchards located in Trás-os-Montes, Northeast Portugal. Selected plants are not irrigated and no phytosanitary treatments were applied. The fruits were dried at room temperature and exposed to sun, as common practice in the region.

For antioxidant compounds extraction, a fine dried powder (20 mesh) of sample ( $3 \mathrm{~g}$ ) was extracted using $50 \mathrm{~mL}$ of methanol at $25^{\circ} \mathrm{C}$ during $60 \mathrm{~min}$. The extracts were filtered through Whatman no. 4 paper and evaporated at $40{ }^{\circ} \mathrm{C}$ to dryness. All the samples were redissolved in water at a concentration of $20 \mathrm{mg} / \mathrm{mL}$ and analysed for their contents in phenols and flavonoids, DPPH radical scavenging activity, reducing power, inhibition of erythrocyte hemolysis, inhibition of $\beta$-carotene bleaching and inhibition of lipid peroxidation.

\subsection{Determination of antioxidants content}

Phenolic concentration in the extracts was estimated by a colorimetric assay based on procedures described by Singleton and Rossi (1965) with some modifications. Basically, $1 \mathrm{~mL}$ of sample was mixed with $1 \mathrm{~mL}$ of Folin and Ciocalteu's phenol reagent. After $3 \mathrm{~min}, 1 \mathrm{~mL}$ of saturated sodium carbonate solution was added to the mixture and adjusted to $10 \mathrm{~mL}$ with distilled water. The reaction was kept in the dark for $90 \mathrm{~min}$, after which the absorbance was read at $725 \mathrm{~nm}$ (Analytik Jena 200-2004 spectrophotometer). Gallic acid was used for constructing the standard curve $\left(0.01-0.4 \mathrm{mM} ; y=2.94848 x-0.09211 ; R^{2}=0.99914\right)$ and the results were expressed as mg of gallic acid equivalents/g of extract (GAEs).

Flavonoid contents in the extracts were determined by a colorimetric method described by Jia et al. (1999) with some modifications. The almond extract $(250 \mu \mathrm{L})$ was mixed with $1.25 \mathrm{~mL}$ of distilled water and $75 \mu \mathrm{L}$ of a $5 \% \mathrm{NaNO}_{2}$ solution. After $5 \mathrm{~min}, 150 \mu \mathrm{L}$ of a $10 \% \mathrm{AlCl}_{3} \cdot \mathrm{H}_{2} \mathrm{O}$ solution was added. After $6 \mathrm{~min}, 500 \mu \mathrm{L}$ of $1 \mathrm{M} \mathrm{NaOH}$ and $275 \mu \mathrm{L}$ of distilled water were added to the mixture. The solution was mixed well and the intensity of pink colour was measured at $510 \mathrm{~nm}$. (+)-cat- echin was used to calculate the standard curve $(0.250-2.500 \mathrm{mM} ; y=0.2903$; $\left.R^{2}=1.0000\right)$ and the results were expressed as $\mathrm{mg}$ of $(+)$-chatequin equivalents (CEs) per $g$ of extract.

\subsection{DPPH radical-scavenging activity}

Various concentrations of almond extracts $(0.3 \mathrm{~mL})$ were mixed with $2.7 \mathrm{ml}$ of methanolic solution containing DPPH radicals $\left(6 \times 10^{-5} \mathrm{~mol} / \mathrm{L}\right)$. The mixture was shaken vigorously and left to stand for $60 \mathrm{~min}$ in the dark (until stable absorption values were obtained). The reduction of the DPPH radical was determined by measuring the absorption at $517 \mathrm{~nm}$. The radical scavenging activity (RSA) was calculated as a percentage of DPPH discolouration using the equation: \% $\mathrm{RSA}=\left[\left(A_{\mathrm{DPPH}}-A_{\mathrm{S}}\right) / A_{\mathrm{DPPH}}\right] \times 100$, where $A_{\mathrm{S}}$ is the absorbance of the solution when the sample extract has been added at a particular level, and $A_{\mathrm{DPPH}}$ is the absorbance of the DPPH solution (Barros et al., 2007). The extract concentration providing $50 \%$ of radicals scavenging activity $\left(\mathrm{EC}_{50}\right)$ was calculated from the graph of RSA percentage against extract concentration. BHA and $\alpha$-tocopherol were used as standards.

\subsection{Reducing power}

Various concentrations of almond constituents extracts $(2.5 \mathrm{~mL})$ were mixed with $2.5 \mathrm{~mL}$ of $200 \mathrm{mmol} / \mathrm{L}$ sodium phosphate buffer ( $\mathrm{pH} 6.6$ ) and $2.5 \mathrm{~mL}$ of $1 \%$ potassium ferricyanide. The mixture was incubated at $50{ }^{\circ} \mathrm{C}$ for $20 \mathrm{~min}$. After $2.5 \mathrm{~mL}$ of $10 \%$ trichloroacetic acid (w/v) were added, the mixture was centrifuged at $1000 \mathrm{rpm}$ for $8 \mathrm{~min}$ (Centorion K24OR-2003 refrigerated centrifuge). The upper layer $(5 \mathrm{~mL})$ was mixed with $5 \mathrm{~mL}$ of deionised water and $1 \mathrm{~mL}$ of $0.1 \%$ of ferric chloride, and the absorbance was measured spectrophotometrically at $700 \mathrm{~nm}$ (Barros et al., 2007). The extract concentration providing 0.5 of absorbance $\left(\mathrm{EC}_{50}\right.$ ) was calculated from the graph of absorbance at $700 \mathrm{~nm}$ against extract concentration. BHA and $\alpha$-tocopherol were used as standards.

\subsection{Inhibition of $\beta$-carotene bleaching}

The antioxidant activity of almond extracts was evaluated by the $\beta$-carotene linoleate model system. A solution of $\beta$-carotene was prepared by dissolving $2 \mathrm{mg}$ of $\beta$-carotene in $10 \mathrm{~mL}$ of chloroform. Two millilitres of this solution were pipetted into a $100 \mathrm{~mL}$ round-bottom flask. After the chloroform was removed at $40{ }^{\circ} \mathrm{C}$ under vacuum, $40 \mathrm{mg}$ of linoleic acid, $400 \mathrm{mg}$ of Tween 80 emulsifier, and $100 \mathrm{~mL}$ of distilled water were added to the flask with vigorous shaking. Aliquots $(4.8 \mathrm{~mL})$ of this emulsion were transferred into different test tubes containing $0.2 \mathrm{~mL}$ of different concentrations of the almond extracts. The tubes were shaken and incubated at $50{ }^{\circ} \mathrm{C}$ in a water bath. As soon as the emulsion was added to each tube, the zero time absorbance was measured at $470 \mathrm{~nm}$ using a spectrophotometer. Absorbance readings were then recorded at 20-min intervals until the control sample had changed colour. A blank, devoid of $\beta$-carotene, was prepared for background subtraction. Lipid peroxidation (LPO) inhibition was calculated using the following equation: LPO inhibition $=(\beta$-carotene content after $2 \mathrm{~h}$ of assay/initial $\beta$-carotene content $) \times 100$ (Barros et al., 2007). The extract concentration providing 50\% antioxidant activity $\left(\mathrm{EC}_{50}\right)$ was calculated from the graph of antioxidant activity percentage against extract concentration. TBHQ was used as standard.

\subsection{Inhibition of erythrocyte hemolysis mediated by peroxyl free radicals}

The antioxidant activity of the almond extracts was measured as the inhibition of erythrocyte hemolysis. Blood was obtained from male ram (Churra Galega Transmontana) of body weight $\sim 67 \mathrm{Kg}$. Erythrocytes separated from the plasma and the buffy coat were washed three times with $10 \mathrm{~mL}$ of $10 \mathrm{mM}$ phosphate buffer saline (PBS) at pH 7.4 (prepared by mixing $10 \mathrm{mM}$ of $\mathrm{NaH}_{2} \mathrm{PO}_{4}$ and $\mathrm{Na}_{2} \mathrm{HPO}_{4}$, and $125 \mathrm{mM}$ of $\mathrm{NaCl}$ in $1 \mathrm{~L}$ of distilled water) and centrifuged at $1500 \mathrm{~g}$ for $5 \mathrm{~min}$. During the last washing, the erythrocytes were obtained by centrifugation at $1500 \mathrm{~g}$ for $10 \mathrm{~min}$. A $0.1 \mathrm{~mL}$ of a $20 \%$ suspension of erythrocytes in PBS was added to $0.2 \mathrm{~mL}$ of $200 \mathrm{mM}$ 2,2'-azobis(2-amidinopropane)dihydrochloride (AAPH) solution (in PBS) and $0.1 \mathrm{~mL}$ of almond extracts. The reaction mixture was shaken gently ( $30 \mathrm{rpm}$ ) while being incubated at $37^{\circ} \mathrm{C}$ for $3 \mathrm{~h}$. The reaction mixture was diluted with $8 \mathrm{~mL}$ of PBS and centrifuged at $3000 \mathrm{~g}$ for $10 \mathrm{~min}$; the absorbance of its supernatant was then read at $540 \mathrm{~nm}$ by a spectrophotometer, after filtration with a syringe filter (cellulose membrane $30 \mathrm{~mm}, 0.20 \mu \mathrm{m}$, Titan). The percentage hemolysis inhibition was calculated by the equation\% hemolysis inhibition $=\left[\left(A_{\mathrm{AAPH}}-A_{\mathrm{S}}\right) / A_{\mathrm{AAPH}}\right] \times 100$, where $A_{\mathrm{S}}$ is the absorbance of the sample containing the almond extract, and $A_{\mathrm{AAPH}}$ is the absorbance of the control sample containing no almond extract (Barros et al., 2007). The extract concentration providing $50 \%$ inhibition $\left(\mathrm{EC}_{50}\right)$ was calculated from the graph of hemolysis inhibition percentage against extract concentration. L-ascorbic acid was used as standard.

In order to explore the kinetic behaviour of the antioxidant properties measured as the inhibition of erythrocyte hemolysis mediated by peroxyl free radicals, another assay was conducted considering the three almond cultivars presenting the best results (Duro Italiano, Ferrastar and Ferraduel). The used method is based on procedures described by Tang and Liu (2007). Basically, after washing three times with phosphate-buffered saline (PBS: $150 \mathrm{mM} \mathrm{NaCl}, 8.1 \mathrm{mM} \mathrm{Na} \mathrm{HPO}_{4}, 1.9 \mathrm{mM}$ 
$\mathrm{NaH}_{2} \mathrm{PO}_{4}$, and $50 \mu \mathrm{M}$ EDTA, pH 7.4) to remove the residual plasma, the erythrocytes were centrifuged at $1700 \mathrm{~g}$ for exactly $10 \mathrm{~min}$ in order to obtain compact erythrocytes for experimental use. Almond extracts at different concentrations and AAPH solution ( $30 \mathrm{mM}$ as the final concentration) were added successively to a $3 \%$ erythrocyte suspension in PBS $(\mathrm{v} / \mathrm{v})$. This mixture was then placed in a $37^{\circ} \mathrm{C}$ thermostatic bath to initiate haemolysis. Aliquots of $1 \mathrm{~mL}$ were collected at adequate intervals and centrifuged at $1700 \mathrm{~g}$ for $5 \mathrm{~min}$ to obtain the supernatant, from which absorbance was measured at $540 \mathrm{~nm}$.

2.8. Inhibition of lipid peroxidation using thiobarbituric acid reactive substances (TBARS)

Brains were obtained from pig (Sus scrofa) of body weight $\sim 150 \mathrm{Kg}$, dissected and homogenized with a polytron in ice-cold Tris- $\mathrm{HCl}$ buffer $(20 \mathrm{mM}, \mathrm{pH} 7.4)$ to produce a $1: 2(\mathrm{w} / \mathrm{v})$ brain tissue homogenate which was centrifuged at $3000 \mathrm{~g}$ for $10 \mathrm{~min}$. An aliquot $(0.1 \mathrm{~mL})$ of the supernatant was incubated with the almond extracts $(0.2 \mathrm{~mL})$ in the presence of $\mathrm{FeSO}_{4}(10 \mu \mathrm{M} ; 0.1 \mathrm{~mL})$ and ascorbic acid $(0.1 \mathrm{mM}$ $0.1 \mathrm{~mL}$ ) at $37{ }^{\circ} \mathrm{C}$ for $1 \mathrm{~h}$. The reaction was stopped by the addition of trichloroacetic acid $(28 \% \mathrm{w} / \mathrm{v}, 0.5 \mathrm{~mL})$, followed by thiobarbituric acid (TBA, $2 \%, \mathrm{w} / \mathrm{v}, 0.38 \mathrm{~mL}$ ), and the mixture was then heated at $80^{\circ} \mathrm{C}$ for $20 \mathrm{~min}$. After centrifugation at $3000 \mathrm{~g}$ for $10 \mathrm{~min}$ to remove the precipitated protein, the colour intensity of the malondialdehyde (MDA)-TBA complex in the supernatant was measured by its absorbance at $532 \mathrm{~nm}$. The inhibition ratio (\%) was calculated using the following formula: Inhibition ratio $(\%)=[(A-B) / A] \times 100 \%$, where $A$ and $B$ were the absorbance of the contro and the compound solution, respectively (Barros et al., 2007). The extract concentration providing $50 \%$ lipid peroxidation inhibition $\left(\mathrm{EC}_{50}\right)$ was calculated from the graph of antioxidant activity percentage against extract concentration. BHA was used as standard.

Table 1

Extraction yields for the different almond cultivars, and corresponding coefficients of variation

\begin{tabular}{lcr}
\hline Cultivars & \multicolumn{1}{c}{$\eta(\%)$} & $\mathrm{CV}(\%)$ \\
\hline Casanova & $10.62 \pm 0.87 \mathrm{abc}$ & 8.19 \\
Duro Italiano & $9.82 \pm 0.56 \mathrm{abc}$ & 5.68 \\
Molar & $11.48 \pm 0.63 \mathrm{ab}$ & 5.53 \\
Orelha de Mula & $13.59 \pm 0.98 \mathrm{a}$ & 7.24 \\
Pegarinhos & $11.52 \pm 2.78 \mathrm{ab}$ & 24.17 \\
Pegarinhos (twin seeds) & $10.33 \pm 1.42 \mathrm{abc}$ & 13.74 \\
Ferraduel & $10.66 \pm 0.72 \mathrm{abc}$ & 6.78 \\
Ferranhês & $11.37 \pm 0.95 \mathrm{ab}$ & 8.37 \\
Ferrastar & $7.53 \pm 0.66 \mathrm{c}$ & 8.72 \\
Guara & $7.95 \pm 1.80 \mathrm{bc}$ & 22.65 \\
\hline
\end{tabular}

In each column different letters mean significant differences between the almond cultivars.

\subsection{Statistical analysis}

For all the experiments three samples of each almond cultivar were analysed and all the assays were carried out in triplicate. The results are expressed as mean values and standard error (SE) of the mean or standard deviation (SD) of the mean. The differences between the almond cultivars were analyzed using one-way analysis of variance (ANOVA) followed by Tukey's HSD Test with $\alpha=0.05$. This treatment was carried out using SAS v. 9.1.3 program.

\section{Results and discussion}

Table 1 presents the extraction yields (expressed as $\mathrm{w} / \mathrm{w}$ percentages) for each almond cultivar. The results are globally similar varying from $7.53 \pm 0.66$ to $13.59 \pm 0.98$, and can be accepted as good if we consider the nutritional composition of almond with a high lipid percentage (Venkatachalam and Shridhar, 2006) and therefore not soluble in polar solvents. However, some differences can be observed regarding the reproducibility of the same results (e.g., $C V=5.53 \%$ in Molar cultivar; $C V=24.17 \%$ for Pegarinhos). Despite the low values obtained for the extraction yields, the antioxidants contents found were good, indicating that the extraction was efficient, especially for Duro Italiano, Ferraduel and Ferrastar cvs. ( $>10 \%)$.

Fig. 1 shows phenol and flavonoid concentrations obtained in the 10 almond cultivars. After an overview of the results we can observed that, in average, the commercial cultivars show higher phenols contents. Surprisingly, Duro Italiano, a regional cultivar revealed the highest content in phenol compounds (163.71 \pm $3.04 \mathrm{mg} / \mathrm{g}$ ). Pegarinhos (twin seeds) cv. revealed the lowest phenols concentration $(9.22 \pm 1.04 \mathrm{mg} / \mathrm{g})$, while Pegarinhos cv. presented the highest contents in flavonoids $(25.02 \pm 8.43 \mathrm{mg} / \mathrm{g})$, showing Ferraduel cv. the lowest content $(6.24 \pm 1.36 \mathrm{mg} / \mathrm{g})$.

Some authors have reported a direct correlation between antioxidant activity and total phenolic content (Velioglu et al., 1998; Ferreira et al., 2007). The antioxidant activity of phenolics may be related to their redox properties, which allow them to act as reducing agents or hydrogen-atom donors, their ability to chelate metals, inhibit lipoxygenase and scavenge free radicals (Decker, 1997). Thus, natural antioxidants function as free-radical scavengers and chain breakers, complexers of pro-oxidant metal ions and quenchers of singlet-oxygen formation (Amarowicz et al., 2004). In food systems, flavonoids can act as free radical scavengers and

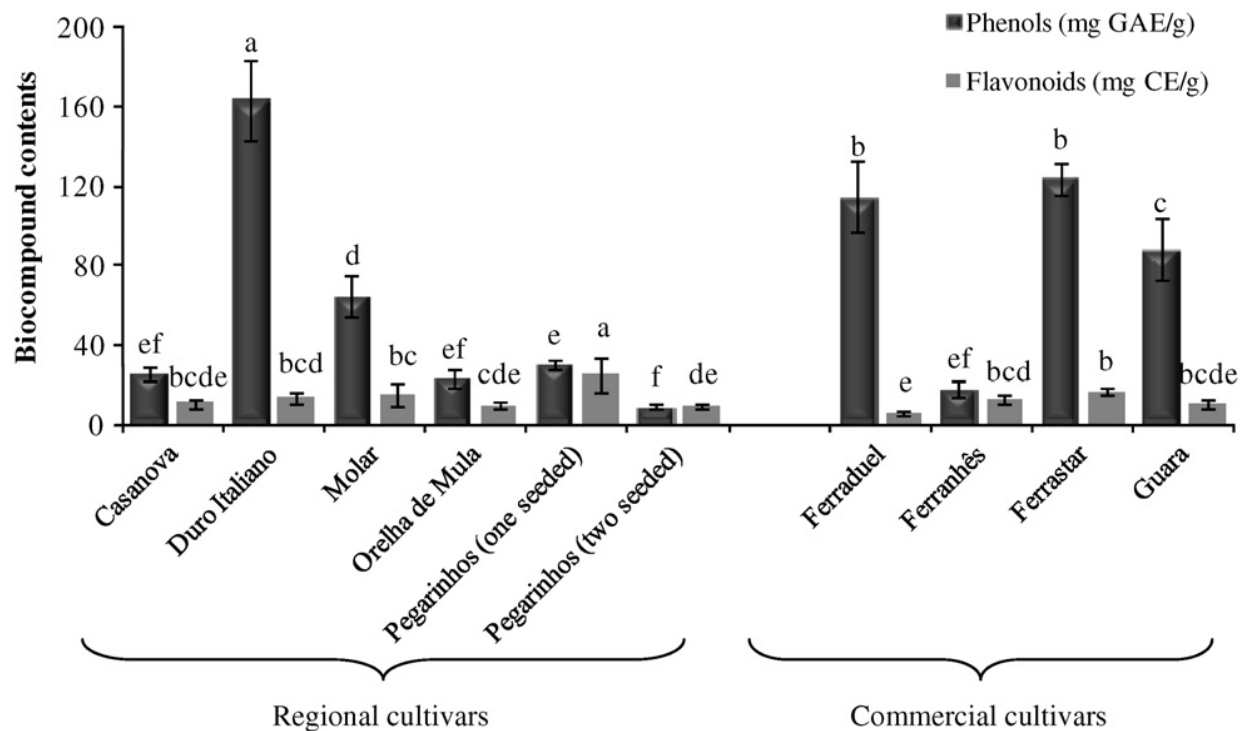

Fig. 1. Phenols and flavonoids contents in different almond cultivars. Each value is expressed as mean \pm standard error. In each column different letters mean significant differences between the almond cultivars. 
terminate the radical chain reactions that occur during the oxidation of triglycerides (Roedig-Penman and Gordon, 1998) and also appear to possess a variety of biological activities, including antioxidant, anti-inflammatory, and vasodilatory actions (Chen et al., 2005). These natural constituents of plant foods have been carefully studied in fruits and vegetables, but less attention has been paid to their presence in whole grains and tree nuts.

Fig. 2 shows antioxidant activity $\mathrm{EC}_{50}$ values of the different almond cultivars, measured by chemical and biochemical assays. Overall, Duro Italiano cv. revealed better antioxidant properties (significantly lower $\mathrm{EC}_{50}$ values; $p<0.05$ ). $\mathrm{The} \mathrm{EC}_{50}$ values obtained for this regional cultivar were very good (less than $0.8 \mathrm{mg} / \mathrm{mL}$ ), particularly for TBARS assay (less than $0.2 \mathrm{mg} / \mathrm{mL}$ ). Two commercial cultivars, Ferraduel and Ferrastar, revealed good antioxidant activity ( $\mathrm{EC}_{50}$ less than $1.5 \mathrm{mg} / \mathrm{mL}$ ), while the other cultivars presented higher $\mathrm{EC}_{50}$ values in all the tested methods.

The $\mathrm{EC}_{50}$ values obtained in lipid peroxidation inhibition by TBARS assay (measured by the colour intensity of MDA-TBA complex) were better than for the inhibition of $\beta$-carotene bleaching caused by linoleate free radical (by neutralizing the linoleate-free radical and other free radicals formed in the system which attack the highly unsaturated $\beta$-carotene models), reducing power

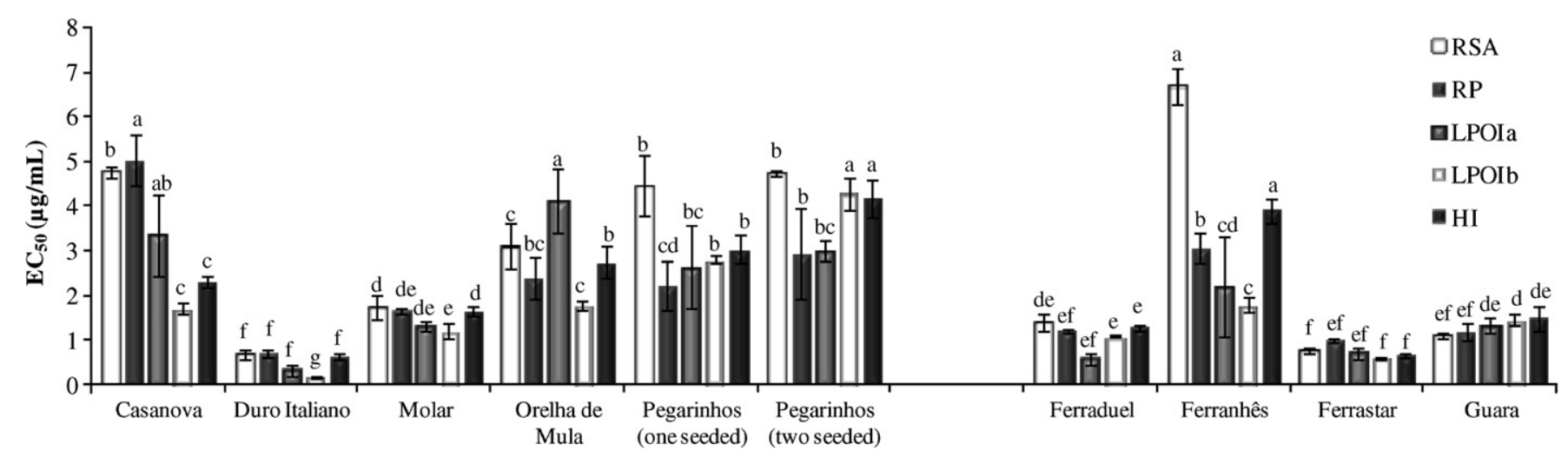

Fig. 2. Radical scavenging activity (RSA), reducing power (RP), lipid peroxidation inhibition using $\beta$-carotene (LPOIa) and thiobarbituric acid reactive substances (LPOIb) and erythrocyte hemolysis inhibition $\mathrm{EC}_{50}$ values of different almond cultivars extracts. Each value is expressed as mean \pm standard error. In each column different letters mean significant differences between the almond cultivars.
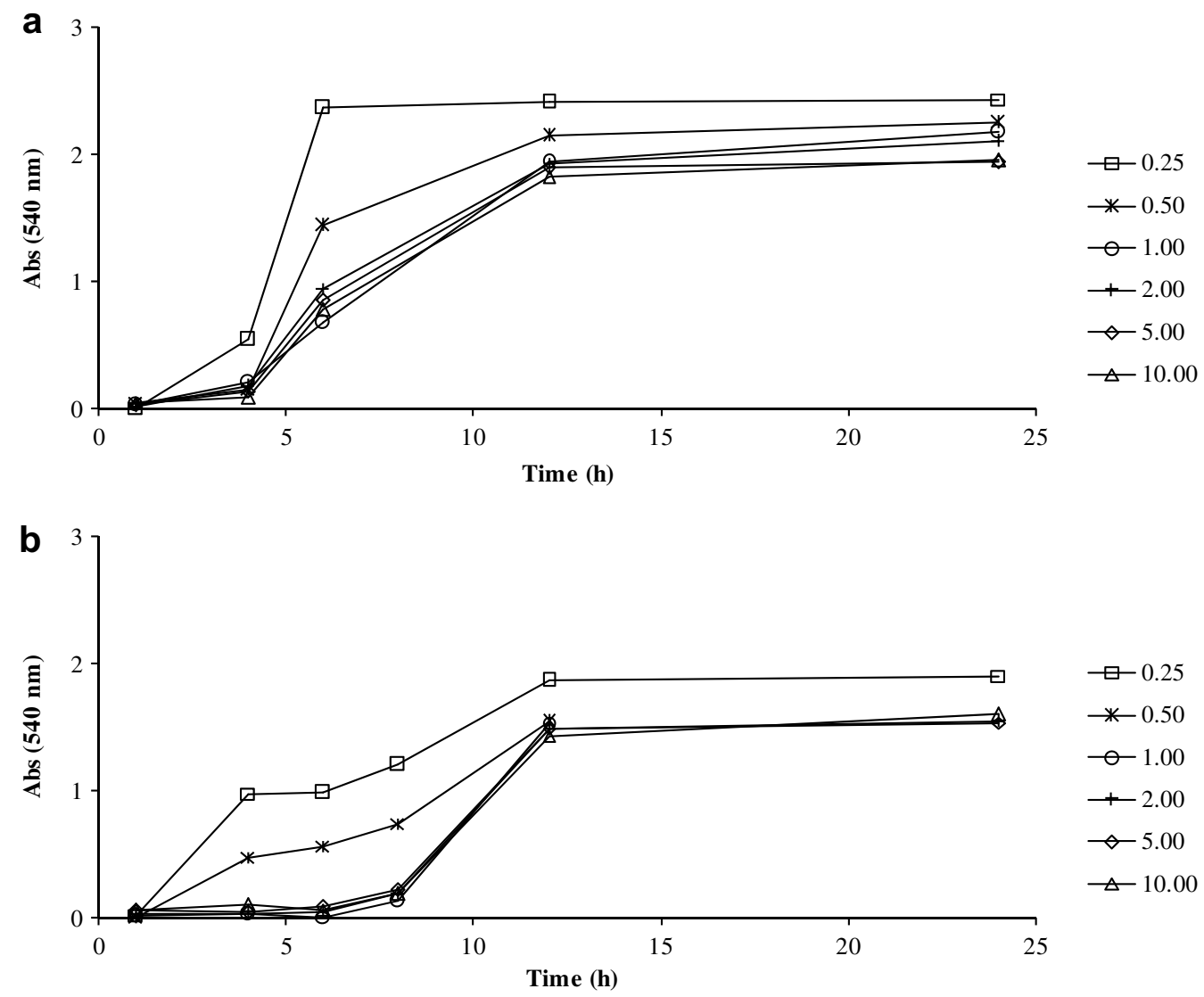

Fig. 3. Hemolysis curves of ram erythrocytes (3.0\% suspension in PBS, pH 7.4) initiated by AAPH ( $30 \mathrm{mM}$ ) at $37{ }^{\circ} \mathrm{C}$ in the presence of regional Duro Italiano Cv. (Fig. $\left.3 \mathrm{a}\right)$ and commercial Ferrastar Cv. (Fig. 3b). 
(measuring the conversion of a $\mathrm{Fe}^{3+} /$ ferricyanide complex to the ferrous form), hemolysis inhibition (evaluating the protective effect of the extracts on hemolysis by peroxyl radical scavenging activity), and scavenging effects on DPPH radicals (measuring the decrease in DPPH radical absorption after exposure to radical scavengers). The assays were performed in the whole extract, since it could be more beneficial than isolated constituents due to additive and synergistic effects of phytochemicals; a bioactive individual component can change its properties in the presence of other compounds present in the extracts (Liu, 2003).

Particularly, for the erythrocyte hemolysis inhibition assay it is known that inhibition of the hemolytic process is time-dependent. It means that the antioxidant activity/protective effect of erythrocytes membrane is only maintained for a determined period. In order to verify the antioxidant activity time for the better almond cultivars, we conducted a second hemolysis inhibition assay with some procedure alterations. It is clear, from the analysis of Fig. 3a (regional cultivar) and b (commercial cultivar), that the maximum antioxidant activity is only maintained for the first $4 \mathrm{~h}$ (very low absorbance values); then it successively decreases, and after a $12 \mathrm{~h}$ period all the red blood cells had suffered hemolysis. It can also be observed a concentration-dependent effect once the higher protective activity (slower absorbance raise) was achieved with the higher almond extract concentration. When erythrocytes are submitted to an oxidative stress, an alteration of the cell membrane is observed. The free radicals are responsible

Table 2

Correlations established between total phenols and antioxidant activity $\mathrm{EC}_{50}$ values $(n=10)$

\begin{tabular}{llllll}
\hline & Linear & & & Exponential & \\
\cline { 2 - 3 } Assay & Equation & $R^{2}$ & & Equation & $R^{2}$ \\
\hline RSA & $y=-0.034 \mathrm{x}+5.178$ & 0.739 & & $y=5.825 \mathrm{e}^{-0.014 \mathrm{x}}$ & 0.886 \\
Reducing power & $y=-0.018 \mathrm{x}+3.398$ & 0.610 & & $y=3.619 \mathrm{e}^{-0.010 \mathrm{x}}$ & 0.850 \\
LPO inhibition & $y=-0.021 \mathrm{x}+3.370$ & 0.784 & & $y=4.073 \mathrm{e}^{-0.015 \mathrm{x}}$ & 0.931 \\
TBARS assay & $y=-0.017 \mathrm{x}+2.826$ & 0.621 & & $y=3.429 \mathrm{e}^{-0.015 \mathrm{x}}$ & 0.808 \\
Hemolysis inhibition & $y=-0.021 \mathrm{x}+3.594$ & 0.825 & & $y=4.042 \mathrm{e}^{-0.012 \mathrm{x}}$ & 0.923 \\
\hline
\end{tabular}

for a lipid peroxidation and a protein oxidation that leads to the formation of hemolytic holes (Bureau et al., 2005), and with the present study we prove the protective effect of almond extracts in erythrocyte hemolysis until $12 \mathrm{~h}$.

The obtained results are in agreement with the phenol contents determined for each sample and showed in Fig. 1. A significantly negative linear correlation $(p<0.008)$ was established between the phenols content and $\mathrm{EC}_{50}$ antioxidant activity values (Table 2). This correlation proves that the samples with highest phenols content show lower $\mathrm{EC}_{50}$ values, confirming that phenolics are likely to contribute to the antioxidant activity of the extracts, as it has been reported in other species (Velioglu et al., 1998; Barros et al., 2007; Sousa et al., 2008). The obtained data were also adjusted to an exponential curve (Table 2) which gave a better approximation with higher coefficient determination values. On the basis of the previously established relationships between $\mathrm{EC}_{50}$ values and total phenols, the $\mathrm{EC}_{50}$ values were estimated according exponential and linear curves (Table 3 ), and compared to experimental values through the error percentage. As it can be observed, the related errors are globally lower in the case of the exponential function. Nevertheless, the smallest error values were obtained for the linear approximation, but only in specific cases. TBARS assay revealed the highest error values, while reducing power assay gave the minor error values, taking into account all the cultivars tested. In the case of Duro Italiano cv., which had already been stated as the one with better antioxidant activity, the theoretical values for the linear approximation could not be calculated for RSA and LPO inhibition assays, probably because the equations obtained are not suitable for phenols concentrations higher than $150 \mathrm{mg} / \mathrm{g}$.

The information stated in Table 3 is particularly useful when the total phenol content is known because it allows the estimation of $\mathrm{EC}_{50}$ values instead of their experimental determination. In future works with the same or other cultivars we can achieve antioxidant activity parameters through phenols determination.

In conclusion, this study revealed a great dependence of antioxidant capacity on the almond cultivar, being a regional cultivar the most active cv., an important feature for its commercial

Table 3

Experimental and theoretical (using linear and exponential approximations) antioxidant activity $\mathrm{EC}_{50}$ values

\begin{tabular}{|c|c|c|c|c|c|c|c|c|c|c|c|}
\hline Assay & $\mathrm{EC}_{50}$ values & Casanova & $\begin{array}{l}\text { Duro } \\
\text { Italiano }\end{array}$ & Molar & $\begin{array}{l}\text { Orelha } \\
\text { de Mula }\end{array}$ & Pegarinhos & $\begin{array}{l}\text { Pegarinhos } \\
\text { twin seeds }\end{array}$ & Ferraduel & Ferranhês & Ferrastar & Guara \\
\hline \multirow[t]{5}{*}{$\overline{\mathrm{RSA}}$} & Experimental & 4.76 & 0.70 & 1.74 & 3.11 & 4.46 & 4.74 & 1.41 & 6.69 & 0.79 & 1.10 \\
\hline & Linear & 4.31 & - & 2.96 & 4.39 & 4.15 & 4.86 & 1.28 & 4.56 & 0.98 & 2.18 \\
\hline & Error (\%) & 9 & - & 41 & 29 & 7 & 2 & 9 & 32 & 19 & 50 \\
\hline & Exponential & 4.07 & 0.59 & 2.34 & 4.21 & 3.82 & 5.12 & 1.17 & 4.51 & 1.03 & 1.70 \\
\hline & Error (\%) & 14 & 16 & 26 & 26 & 14 & 7 & 17 & 33 & 23 & 35 \\
\hline \multirow[t]{5}{*}{ Reducing power } & Experimental & 5.03 & 0.71 & 1.67 & 2.41 & 2.23 & 2.94 & 1.23 & 3.06 & 1.01 & 1.19 \\
\hline & Linear & 2.94 & 0.45 & 2.22 & 2.98 & 2.85 & 3.23 & 1.33 & 3.07 & 1.17 & 1.81 \\
\hline & Error (\%) & 42 & 37 & 25 & 19 & 22 & 9 & 8 & 0 & 14 & 34 \\
\hline & Exponential & 2.80 & 0.70 & 1.89 & 2.87 & 2.68 & 3.30 & 1.15 & 3.03 & 1.05 & 1.50 \\
\hline & Error (\%) & 44 & 14 & 12 & 16 & 17 & 11 & 7 & 1 & 4 & 21 \\
\hline \multirow[t]{5}{*}{ LPO inhibition } & Experimental & 3.35 & 0.34 & 1.32 & 4.12 & 2.64 & 3.00 & 0.58 & 2.20 & 0.70 & 1.33 \\
\hline & Linear & 2.83 & - & 2.00 & 2.88 & 2.74 & 3.18 & 0.96 & 2.99 & 0.78 & 1.52 \\
\hline & Error (\%) & 16 & - & 34 & 30 & 4 & 6 & 40 & 26 & 10 & 12 \\
\hline & Exponential & 2.77 & 0.35 & 1.53 & 2.88 & 2.59 & 3.55 & 0.73 & 3.10 & 0.64 & 1.09 \\
\hline & Error (\%) & 17 & 3 & 14 & 30 & 2 & 15 & 21 & 29 & 9 & 18 \\
\hline \multirow[t]{5}{*}{ TBARS assay } & Experimental & 1.72 & 0.18 & 1.22 & 1.79 & 2.82 & 4.29 & 1.10 & 1.80 & 0.59 & 1.46 \\
\hline & Linear & 2.39 & 0.04 & 1.72 & 2.43 & 2.31 & 2.67 & 0.88 & 2.52 & 0.73 & 1.33 \\
\hline & Error (\%) & 28 & 78 & 29 & 26 & 18 & 38 & 20 & 29 & 19 & 9 \\
\hline & Exponential & 2.33 & 0.29 & 1.29 & 2.42 & 2.18 & 2.99 & 0.61 & 2.61 & 0.54 & 0.91 \\
\hline & Error (\%) & 26 & 38 & 5 & 26 & 23 & 30 & 44 & 31 & 8 & 37 \\
\hline \multirow{5}{*}{ Hemolysis inhibition } & Experimental & 2.30 & 0.63 & 1.65 & 2.75 & 3.05 & 4.16 & 1.28 & 3.90 & 0.68 & 1.50 \\
\hline & Linear & 3.06 & 0.16 & 2.23 & 3.11 & 2.96 & 3.40 & 1.19 & 3.21 & 1.00 & 1.74 \\
\hline & Error (\%) & 25 & 75 & 26 & 12 & 3 & 18 & 7 & 18 & 32 & 14 \\
\hline & Exponential & 2.97 & 0.57 & 1.85 & 3.06 & 2.81 & 3.62 & 1.02 & 3.25 & 0.92 & 1.40 \\
\hline & Error (\%) & 8 & 10 & 11 & 11 & 8 & 13 & 20 & 17 & 26 & 7 \\
\hline
\end{tabular}


valorisation and even for selective cultivation or hybridization with different cultivars. In these practices, it should be considered that the concentration and composition of phenolic compounds in plants is influenced by a large number of factors such as climate and agricultural conditions. For instance, the use of pesticides reduces the amounts of phenols, so it is advised to apply biological agriculture conditions (Lombardi-Boccia et al., 2004). Almond extracts proved to have radical scavenging activity and lipid peroxidation inhibition capacity in liposome solution, ram erythrocytes membranes, and pig brain cells. The exact time in which almond extracts avoid erythrocyte hemolysis was also determined. Also, the antioxidant activity was correlated with phenols content in an exponential approximation; this could indicate that after a determine value, the phenols have an improved protective effect.

\section{Conflict of interest statement}

The authors declare that there are no conflicts of interest.

\section{Acknowledgements}

The authors are grateful to Foundation for Science and Technology (Portugal) for financial support to J.C.M. Barreira (SFRH/BD/ 29060/2006) and INTERREG IIIA project PIREFI.

\section{References}

Amarowicz, R., Pegg, R.B., Rahimi-Moghaddam, P., Barl, B., Weil, J.A., 2004. Freeradical scavenging capacity and antioxidant activity of selected plant species from the Canadian prairies. Food Chem. 84, 551-562.

Barros, L., Baptista, P., Ferreira, I.C.F.R., 2007. Effect of Lactarius piperatus fruiting body maturity stage on antioxidant activity measured by several biochemical assays. Food Chem. Toxicol. 45, 1731-1737.

Bureau, A., Lahet, J.-J., Lenfant, F., Bouyer, F., Petitjean, M., Chaillot, B., Freysz, M., 2005. Optimization of a model of red blood cells for the study of antioxidant drugs, in terms of concentration of oxidant and phosphate buffer. Biomed. Pharmacother. 59, 341-344

Chen, C.-Y., Milbury, P.E., Lapsley, K., Blumberg, J.B., 2005. Flavonoids from almond skins are bioavailable and act synergistically with vitamins $C$ and $E$ to enhance hamster and human LDL resistance to oxidation. J. Nutr. 135, 1366-1373.

Cordeiro, V., Monteiro, A., 2001. Almond growing in Trás-os-Montes region (Portugal). Acta Horticult. 591, 161-165.

Decker, E.A., 1997. Phenolics: prooxidants or antioxidants? Nutr. Rev. 55, 396-407.

Donovan, J.L., Meyer, A.S., Waterhouse, A.L., 1998. Phenolic composition and antioxidant activity of prunes and prunes juice (Prunus domestica). J. Agric. Food Chem. 46, 1247-1252.

Ferreira, I.C.F.R., Baptista, P., Vilas-Boas, M., Barros, L., 2007. Free-radical scavenging capacity and reducing power of wild edible mushrooms from northeast Portugal. Food Chem. 100, 1511-1516.

Jia, Z., Tang, M., Wu, J., 1999. The determination of flavonoid contents in mulberry and their scavenging effects on superoxide radicals. Food Chem. 64, 555-559.

Liu, R.H., 2003. Health benefits of fruits and vegetables are from additive and synergistic combination of phytochemicals. Am. J. Clin. Nutr. 78, 517S-520S-9.
Lombardi-Boccia, G., Lucarini, M., Lanzi, S., Aguzzi, A., Cappelloni, M., 2004. Nutrients and antioxidant molecules in yellow plums (Prunus domestica L.) from conventional and organic productions: a comparative study. J. Agric. Food Chem. 52, 90-94.

Martínez, J.M., Granado, J.M., Montanr, D., Salvadó, J., Farriol, X., 1995. Fractionation of residual lignocellulosics by dilute-acide prehydrolysis and alkalina extraction: application to almond shells. Bioresource Technol. 52, 59-67.

Martins, M., Tenreiro, R., Oliveira, M.M., 2003. Genetic relatedness of Portuguese almond cultivars assessed by RAPD and ISSR markers. Plant Cell Rep. 22, 7178.

Milbury, P.E., Chen, C.-Y., Dolnikowski, G.G., Blumberg, J.B., 2006. Determination of flavonoids and phenolics and their distribution in almonds. J. Agric. Food Chem. 54, 5027-5033.

Moure, A., Pazos, M., Medina, I., Domínguez, H., Parajó, J.C., 2007. Antioxidant activity of extracts produced by solvent extraction of almond shells acid hydrolysates. Food Chem. 101, 193-201.

Pellegrini, N., Serafini, M., Salvatore, S., Del Rio, D., Bianchi, M., Brighenti, F., 2006. Total antioxidant capacity of spices, dried fruits, nuts, pulses, cereals and sweets consumed in Italy assessed by three different in vitro assays. Mol. Nutr. Food Res. 50, 1030-1038.

Pereira, J.A., Pereira, A.P.G., Ferreira, I.C.F.R., Valentão, P., Andrade, P.B., Seabra, R., Estevinho, L., Bento, A., 2006. Table olives from Portugal: phenolic compounds, antioxidant potential, and antimicrobial activity. J. Agric. Food Chem. 54, 84258431.

Pinelo, M., Rubilar, M., Jerez, M., Sineiro, J., Núñez, M.J., 2004. Extraction of antioxidant phenolics from almond hulls (Prunus amygdalus) and pine sawdust (Pinus pinaster). Food Chem. 85, 267-273.

Rabinowitz, I. N. 2004. Dietary fiber, process for preparing it, and augmented dietary fiber from almond hulls. US Patent, US 0018255.

Roedig-Penman, A., Gordon, M.H., 1998. Antioxidant properties of myricetin and quercetin in oil and emulsions. J. Am. Oil Chem. Soc. 75, 169-180.

Sang, S., Lapsley, K., Jeong, W.-S., Lachance, P.A., Ho, C.H., Rosen, R.T., 2002a. Antioxidative phenolic compounds isolated from almond skins (Prunus amygdalus Batsch). J. Agric. Food Chem. 50, 2459-2463.

Sang, S., Lapsley, K., Rosen, R.T., Ho, C.H., 2002b. New prenilated benzoic acid and other constituents from almond hulls (Prunus amygdalus Batsch). J. Agric. Food Chem. 50, 607-609.

Singleton, V.L., Rossi Jr., J.A., 1965. Colorimetric of total phenolics with phosphomolybdic-phosphotungstic acid reagents. Am. J. Enol. Viticult. 16, 144-158.

Sousa, A., Ferreira, I.C.F.R., Barros, L., Bento, A., Pereira, J.A., 2008. Effect of solvent and extraction temperatures on the antioxidant potential of traditional stoned table olives "alcaparras". LWT-Food Sci. Technol. 41, 739-745.

Subhashinee, S.K.W., Mamdouh, M.A.-Z., Shahidi, F., 2006. Antioxidant polyphenols in almond and its coproducts. J. Agric. Food Chem. 54, 312-318.

Takeoka, G.R., Dao, L.T., Teranishi, R., Wong, R., Flessa, S., Harden, L., 2000. Identification of three triterpenoids in almond hulls. J. Agric. Food Chem. 48, 3437-3439.

Takeoka, G.R., Dao, L.T., 2003. Antioxidant constituents of almond (Prunus dulcis (Mill) D.A. Webb) hulls. J. Agric. Food Chem. 51, 496-501.

Tang, Y.-Z., Liu, Z.-Q., 2007. Free-radical-scavenging effect of carbazole derivatives on AAPH-induced haemolysis of human erythrocytes. Bioorg. Med. Chem. 15, 1903-1913.

Velioglu, Y.S., Mazza, G., Gao, L., Oomah, B.D., 1998. Antioxidant activity and total phenolics in selected fruits, vegetables, and grain products. J. Agric. Food Chem. $46,4113-4117$.

Venkatachalam, M., Shridhar, K.S., 2006. Chemical composition of selected edible nut seeds. J. Agric. Food Chem. 54, 4705-4714.

Wang, H., Nair, M.G., Strasburg, G.M., Booren, A.M., Gray, J.I., 1999. Novel antioxidant compounds from tart cherries (Prunus cerasus). J. Nat. Prod. 62, 86-88. 